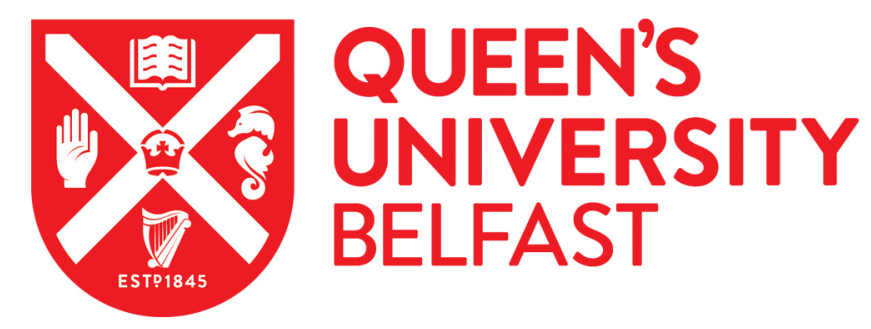

\title{
Religious affiliation and mortality in northern ireland: beyond Catholic and Protestant
}

O'Reilly, D., \& Rosato, M. (2008). Religious affiliation and mortality in northern ireland: beyond Catholic and Protestant. Social Science \& Medicine, 66(7), 1637-1645. https://doi.org/10.1016/j.socscimed.2007.12.004

Published in:

Social Science \& Medicine

Queen's University Belfast - Research Portal:

Link to publication record in Queen's University Belfast Research Portal

\section{General rights}

Copyright for the publications made accessible via the Queen's University Belfast Research Portal is retained by the author(s) and / or other copyright owners and it is a condition of accessing these publications that users recognise and abide by the legal requirements associated with these rights.

Take down policy

The Research Portal is Queen's institutional repository that provides access to Queen's research output. Every effort has been made to ensure that content in the Research Portal does not infringe any person's rights, or applicable UK laws. If you discover content in the Research Portal that you believe breaches copyright or violates any law, please contact openaccess@qub.ac.uk. 


\title{
Religious affiliation and mortality in Northern Ireland: Beyond Catholic and Protestant
}

\author{
Dermot O’Reilly, Michael Rosato* \\ Epidemiology and Public Health, Queen's University, Mulhouse Building, Belfast BT12 6BJ, United Kingdom
}

Available online 25 January 2008

\begin{abstract}
There has been little recent research in Europe exploring the relationship between religion and health. In Northern Ireland previous analysis has tended to divide the population dichotomously as Catholic and Protestant, ignoring the diversity inherent in the Protestant community. This study used a census-based longitudinal study of the enumerated population with five-years follow-up (covering the period 2001-2006) to examine variation in overall and cause-specific mortality by religious affiliation within Northern Ireland. Six groups were defined: Catholics; Presbyterians; Church of Ireland; Methodists; Other (mostly fundamentalist) Christians; and 'Other/not-stated'. Catholics had higher mortality than non-Catholics, though this disappeared after adjustment for socio-economic status. Church of Ireland members had the highest overall mortality in the fully adjusted models, due to their higher risk of cardiovascular disease. 'Other Christians' had lowest all-cause mortality and particularly low mortality from alcohol-related deaths and lung cancer. These findings point to an association between religious affiliation, behaviour and lifestyle suggesting that, even in relatively secular societies, it is a population attribute that should be given more consideration in studies of population health.
\end{abstract}

(C) 2008 Elsevier Ltd. All rights reserved.

Keywords: Northern Ireland; Mortality; Record linkage; Religious affiliation; UK; Church denomination

\section{Background}

The relationship between religious affiliation and health has, until recently, been of limited interest for epidemiological research in the United Kingdom (UK), with both increasing secularization and the lowkey nature of mainstream 'native' religious traditions probably contributing to this. While European research on the possible salutary effects of religiosity goes back

\footnotetext{
* Corresponding author. Tel.: +44 2890 632726; fax: +44 2890 231907.

E-mail addresses: d.oreilly@qub.ac.uk (D. O’Reilly), m.rosato@ qub.ac.uk (M. Rosato).
}

at least to Durkheim's classic 19th Century work on suicide (Durkheim, 1959) most recent research comes from the USA (Hummer, Ellison, Rogers, Moulton, \& Romero, 2004; Koenig, McCullough, \& Larson, 2001; McCullough, Hoyt, Larson, Koenig, \& Thoresen, 2000) where there is specific interest in the more exacting religious groups such as Mormons and Seventh-day Adventists (Heuch, Jacobsen, \& Fraser, 2005; Levin, 1994; Philips, Lemon, Beeson, \& Kuzma, 1978). However, the increasingly diverse cultural character of UK society will ensure that religion is studied, either directly, because of its putative communitarian qualities, or in proxy form through analysis of ethnic minority health. Given this, some research interest is evident: in 
Scotland, where recent work emphasises country of birth, with Catholicism often taken as a proxy for Irish ancestry (Abbotts, Williams, Ford, Hunt, \& West, 1997; Williams, 1994); and in Northern Ireland, partly in relation to the recent civil unrest (or 'Troubles') that has been a consistent feature of the socio-political landscape. A further impetus to research in Northern Ireland is the recently developed 'Equality Agenda', an initiative designed to erode the pre-conditions of unrest, comprising elements of Human Rights legislation, local equality legislation and poverty reduction mechanisms (DRD-NI, 2007).

Research into religion and health in Northern Ireland has been limited (Campbell, 1993), both in scope and because of inherent data limitations. Past research has defined the population dichotomously as Catholic or Protestant, and while this may be driven by attempts to understand the gross effects of state and social structures dominating the recent past, it ignores the diversity inherent in Protestant communities. Additionally, mortality analysis to date has been ecological in nature, leaving it open to criticism, including the inability to control for individual differences in socio-economic circumstances. Finally, no research has yet examined variation in cause-specific mortality.

Current research shows that previous higher fertility amongst Catholics, while converging in recent years (Compton, 1986; NISRA, 1997), has left the legacy that Catholics, on average, have both a younger age profile and larger average household size (O'Grada \& Walsh, 1995). Through normal processes of population momentum this should ensure the Catholic population will proportionately increase in the coming years. Historically Catholics have been more economically disadvantaged, with higher unemployment levels, lower average household income and a greater dependency on state social security benefits (Borooah, 1999, 2000; NISRA, 2000). Studies conducted around the time of the 1981 and 1991 Censuses showed both Catholic over-representation in areas of disadvantage and higher mortality in areas with greater proportions of Catholics - differences, however, which disappeared after controlling for area-level material disadvantage (O'Reilly \& Stevenson, 1998; Stringer, 1992). Two studies, based on secondary analysis of population surveys, have demonstrated poorer health amongst Catholics, explained by differences in socio-economic status between the communities (Campbell \& Stevenson, 1993; O'Reilly \& Browne, 2001). There is also evidence that Catholics are more likely to have poorer mental health and to have been exposed to higher stress levels, including those directly related to the unrest (McKittrick, Kelters, Feeney, \& Thornton, 1999; O'Reilly \& Stevenson, 2003).

This study extends previous research on denominational difference: by focusing on mortality using indicators derived at the level of the individuals included in the study rather than area-level data; by (in the main) treating the non-Catholic population as different denominations, rather than a summary Protestant group; and by examining for differences in cause-specific mortality.

\section{Data and methods}

In 2006 the Northern Ireland Statistics and Research Agency (NISRA) undertook an exercise linking the whole enumerated 2001 Census population to deaths to Northern Ireland residents in the five years following the census. Details of this are described elsewhere (O'Reilly, Rosato, \& Connolly, in press). These data were anonymised, held in a safe setting by NISRA and made available to the researchers. All attributes of the cohort were as described on the census record. The 2001 Census included two questions on religious affiliation: one asking current adherence and a supplement (answered if the first was not) asking the denomination in which the person was 'brought up'. This had been included because previous censuses had shown that a sizable minority had not answered the main question. In 2001, 13.9\% of the population didn't answer the question and for these the supplementary information was used. Five Christian denominations were defined: Roman Catholics; and four Protestant groups - the Presbyterian Church in Ireland, Church of Ireland, Methodist Church in Ireland, and Other, mainly fundamentalist, Christian groups. This small 'Other Christian' group comprised mostly fundamentalist Protestant denominations, such as Free Presbyterians (constituting $38.6 \%$ of this group), Baptists and Brethren. The final, smallest category comprised both non-Christians and those who responded 'none' to both questions ('Other/none' in the text). Historically, Presbyterianism has its roots in 17th Century Scotland and a severe form of Protestant Reform. It is democratic in structure and this, at times, lends itself to both (fundamentalist) schism and 'dissenting' political and religious radicalism. The Church of Ireland, however, is from a less radical English Anglican tradition (defining itself as 'Catholic and Reformed'). They were, until 1871, the established (state sanctioned) Church in Ireland, drawing tithes from other 
denominations, a situation causing resentment and occasional violent reaction from both Catholic and Dissenting traditions.

Baseline demographic data comprised age, sex and marital status (categorised as married/cohabiting; never married and not living as part of a couple; widowed; and separated or divorced). Four measures indicating socioeconomic status were included: housing tenure (owner, private renting, and social renting); car availability (two or more cars, one only, and no access); the National Statistics Socio-economic Classification (comprising eight categories from professional to routine occupation

Table 1

The population of Northern Ireland enumerated at the 2001 Census: demographic, socio-economic and area characteristics for those aged 25-74 at the census

\begin{tabular}{|c|c|c|c|c|c|c|c|}
\hline & Catholic & Presbyterian & Church of Ireland & Methodist & Other Christian & Other or none & Total \\
\hline Number & 366,959 & 228,171 & 169,023 & 39,342 & 70,931 & 58,208 & 932,634 \\
\hline \multicolumn{8}{|l|}{ Age } \\
\hline $25-34$ & 26.6 & 21.4 & 21.2 & 20.6 & 25.7 & 28.4 & 24.1 \\
\hline $35-44$ & 27.0 & 23.7 & 23.5 & 23.6 & 24.9 & 26.5 & 25.3 \\
\hline $45-54$ & 20.6 & 20.8 & 21.0 & 21.0 & 20.5 & 20.0 & 20.7 \\
\hline $55-64$ & 15.0 & 19.0 & 19.0 & 19.3 & 17.1 & 14.9 & 17.0 \\
\hline $65-74$ & 10.7 & 15.1 & 15.3 & 15.5 & 11.8 & 10.3 & 12.9 \\
\hline \multicolumn{8}{|l|}{ Sex } \\
\hline Male & 47.3 & 48.8 & 47.9 & 46.8 & 48.9 & 53.7 & 48.3 \\
\hline Female & 52.7 & 51.2 & 52.1 & 53.2 & 51.1 & 46.3 & 51.7 \\
\hline \multicolumn{8}{|l|}{ Marital status } \\
\hline Married/cohabiting & 61.7 & 67.6 & 64.6 & 67.5 & 71.0 & 57.9 & 64.4 \\
\hline Single & 23.9 & 17.8 & 18.3 & 16.6 & 16.4 & 25.4 & 20.6 \\
\hline Widowed & 4.8 & 5.4 & 6.1 & 5.7 & 4.1 & 4.2 & 5.2 \\
\hline Separated/divorced & 9.7 & 9.2 & 10.9 & 10.2 & 8.4 & 12.5 & 9.9 \\
\hline \multicolumn{8}{|l|}{ Housing tenure } \\
\hline Owner & 78.2 & 84.2 & 79.2 & 83.2 & 79.8 & 73.9 & 79.9 \\
\hline Private renting & 5.9 & 4.6 & 5.2 & 4.7 & 10.6 & 10.4 & 6.1 \\
\hline Social renting & 15.9 & 11.3 & 15.6 & 12.1 & 9.6 & 15.7 & 14.0 \\
\hline \multicolumn{8}{|l|}{ Car availability } \\
\hline Two or more & 37.4 & 46.5 & 39.7 & 41.3 & 46.3 & 36.4 & 40.8 \\
\hline One only & 44.8 & 41.4 & 44.1 & 44.5 & 43.6 & 45.4 & 43.8 \\
\hline None & 17.7 & 12.1 & 16.2 & 14.3 & 10.2 & 18.2 & 15.4 \\
\hline \multicolumn{8}{|l|}{ Education } \\
\hline University level & 17.6 & 16.1 & 14.5 & 16.0 & 20.2 & 21.6 & 17.0 \\
\hline A-level or equivalent & 6.0 & 5.9 & 5.4 & 6.2 & 7.5 & 7.3 & 6.1 \\
\hline O-level or equivalent & 28.7 & 30.8 & 29.2 & 31.5 & 32.9 & 30.6 & 29.9 \\
\hline No qualifications & 47.7 & 47.3 & 51.0 & 46.4 & 39.4 & 40.5 & 47.1 \\
\hline \multicolumn{8}{|l|}{ NS-SEC } \\
\hline Managerial or professional & 27.4 & 29.4 & 27.3 & 30.4 & 35.1 & 31.6 & 30.0 \\
\hline Intermediate & 9.6 & 13.1 & 12.4 & 14.5 & 13.4 & 12.6 & 8.7 \\
\hline Self-employed & 10.7 & 11.3 & 8.8 & 8.2 & 10.6 & 9.5 & 10.2 \\
\hline Lower supervisor & 8.5 & 9.8 & 10.3 & 10.2 & 8.4 & 8.7 & 9.2 \\
\hline Routine & 34.3 & 31.7 & 35.6 & 32.4 & 28.6 & 28.0 & 33.0 \\
\hline Not working & 9.0 & 4.5 & 5.4 & 4.1 & 3.3 & 8.4 & 6.6 \\
\hline Student & 0.6 & 0.3 & 0.3 & 0.3 & 0.6 & 1.1 & 0.5 \\
\hline \multicolumn{8}{|l|}{ Population density } \\
\hline Quintile: least dense & 24.2 & 19.1 & 17.0 & 9.2 & 16.0 & 13.2 & 19.7 \\
\hline 2nd & 18.6 & 22.5 & 21.6 & 19.2 & 22.4 & 20.0 & 20.5 \\
\hline $3 r d$ & 19.7 & 21.1 & 21.1 & 20.2 & 20.9 & 21.3 & 20.5 \\
\hline 4th & 17.6 & 20.9 & 22.3 & 26.3 & 21.8 & 22.1 & 20.2 \\
\hline Quintile: most dense & 20.0 & 16.4 & 17.9 & 25.2 & 19.1 & 23.4 & 19.1 \\
\hline
\end{tabular}

Source: Northern Ireland Longitudinal Study (Mortality Study).

All numbers given as percentages except as stated. 
classes, see Table 1) (Rose \& Pevalin, 2002); and education (ranked: university level/equivalent; 'A-level'/ equivalent; 'O-level'/equivalent; and no qualifications). Population density at census super-output area of residence (average population size 1914) was derived and included as a proxy for the urban-rural character of address, as previous analysis has indicated higher mortality in urban areas, especially for lung cancer and respiratory disease (O'Reilly et al., in press).

All deaths were coded to the International Classification of Disease Revision10. To examine the impact of lifestyle a category of deaths related to alcohol consumption was generated. This was derived from a list of causes proposed by the United Kingdom Office for National Statistics (ONS) 'for high-level public health monitoring of alcohol-related deaths' and recently used by the General Register Office for Scotland in producing its annual statistics (GRO-Scotland, 2007; ONS, 2007).

The mortality analysis, of linked deaths occurring during five post-census years (2001-2006), was carried out using Cox Proportional Hazards modelling in Stata9.0 (StataCorp, 2005). In the census social class and education were coded only for those aged less than 75 years. Restricting analysis to include only those aged 25-74 was a compromise, allowing both education to have been completed for most people, and the socio-economic data to be applied to the whole analysis population.

\section{Results}

Of those aged 25-74 years at census, Catholics formed the largest group (39.3\% of the population). Presbyterians and Church of Ireland members followed with $24.5 \%$ and $18.1 \%$, respectively, with Methodists and Other Christians accounting for $11.8 \%$. Catholics had the youngest age structure with $53.6 \%$ aged $25-$ 44 and $10.7 \%$ aged $65-74$, with only the small 'Other/ none' group having a slightly younger profile (Table 1). Catholics and Church of Ireland members had similar socio-economic profiles - more likely to live in social rented accommodation and be in semi-routine and routine jobs, and less likely to have car access. Catholic unemployment levels were high $(9.0 \%)$ compared to the whole population $(6.6 \%)$. Educational attainment was highest for the Other Christian and 'Other/none' groups, followed by Catholics. Finally, Other Christians had the highest proportions in managerial/professional classes, followed by the 'Other/none' group.

Protestants and Catholics in Northern Ireland mostly live in spatially segregated communities: at the 2001 Census $64.5 \%$ of people lived in electoral wards which comprised at least $75 \%$ of people from the same Protestant or Catholic background (with $40.1 \%$ in wards which were more than $90 \%$ homogeneous). Fig. 1a-c shows this distribution for the three main denominations, all determined to some extent by history. Catholics predominate in the west and south of Northern Ireland, and in the west of Belfast (see insert, Fig. 1a); with Presbyterians concentrated in the rural north and east; and the Church of Ireland mostly found in a broad band spreading south and west from Belfast. The remaining smaller groups are not shown. They also follow 'historic' patterns: 'Other Christians' mirror the Presbyterian pattern, and Methodists the Church of Ireland patterns. The 'Other/none' group is centred on Belfast and its environs.

There were 29,271 deaths in the five-year follow-up period: $16,795(57.3 \%)$ to men and $12,476(42.7 \%)$ to women. A separate analysis (not presented) with sex entered as a covariate showed a significant interaction between sex and denomination (the change in the $\times 2$ $\log$ likelihood associated with the model was 14.6 on five degrees of freedom: $P$-value $=0.012$ ), evidence that the mortality experience of males and females differed within denomination and that analysis stratified by sex was appropriate. In fully adjusted models (Table 2) the summary non-Catholic group showed significantly lower risks when compared against Catholics $(\mathrm{HR}=0.92: 95 \% \mathrm{CI}=0.89,0.95$ and $\mathrm{HR}=0.91$ : $\mathrm{CI}=0.88,0.94$ for men and women, respectively). Church of Ireland members had risk profiles similar to Catholics, while 'Other Christians' had risks significantly lower than the summary non-Catholic group. Finally, in models fully adjusted for demographic and socio-economic factors, differences between Catholics and non-Catholics disappeared for men, and were reduced for women $(\mathrm{HR}=0.96$ : $\mathrm{CI}=0.92,1.00)$. Church of Ireland members remained with the highest overall mortality risks $(\mathrm{HR}=1.05$ and 1.04 for men and women, respectively). Again, 'Other Christians' had the lowest overall mortality for both males and females. Presbyterian women also had lower mortality than their Catholic peers.

Cause-specific mortality is presented in Tables 3 (men) and 4 (women), models fully adjusted for demographic and socio-economic factors. Church of Ireland members (with highest all-cause mortality) were also most at risk from circulatory disease: in women this was due to a $20 \%$ excess risk of death from ischaemic heart disease, while men had higher risks for both ischaemic heart disease and stroke, though only the hazard ratios for women were significant. 'Other Christians' were at lowest risk from most 
a

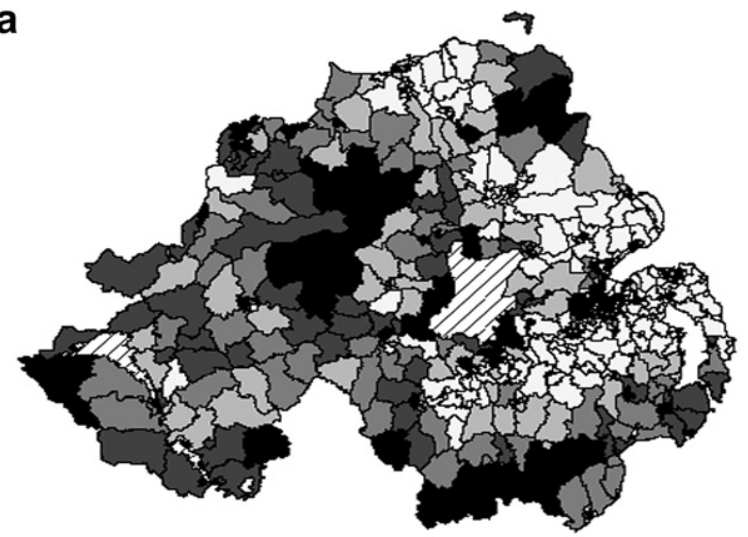

b

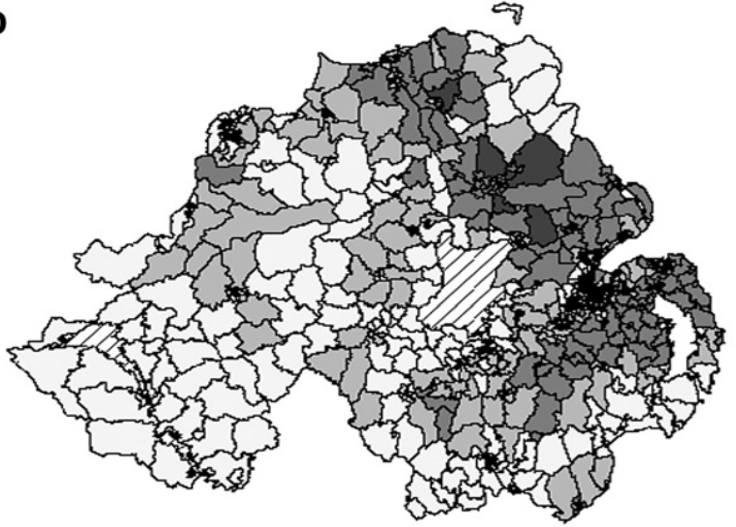

C

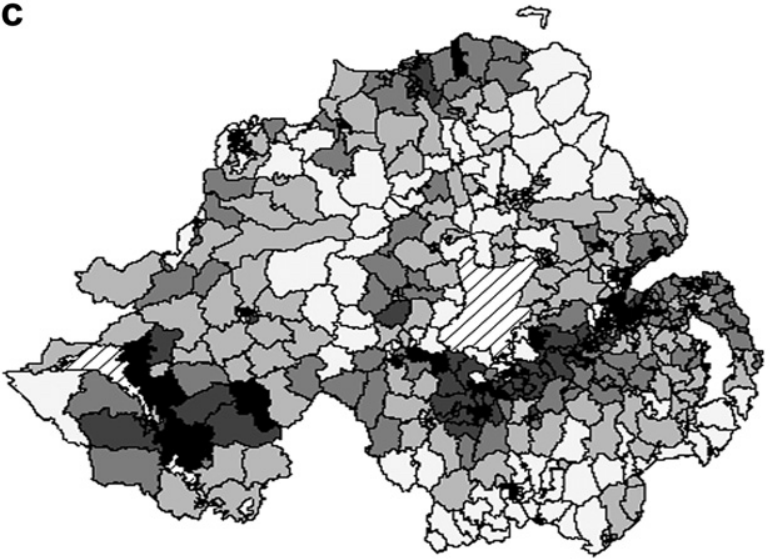

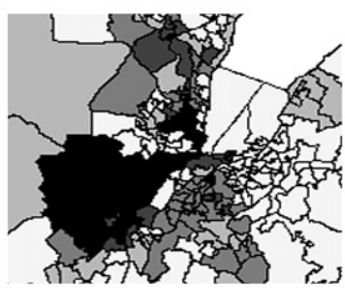

$\%$ Rom an Catholic $\square$ 40-59 $0-19$

$20-39$

$60-79$

$80-100$
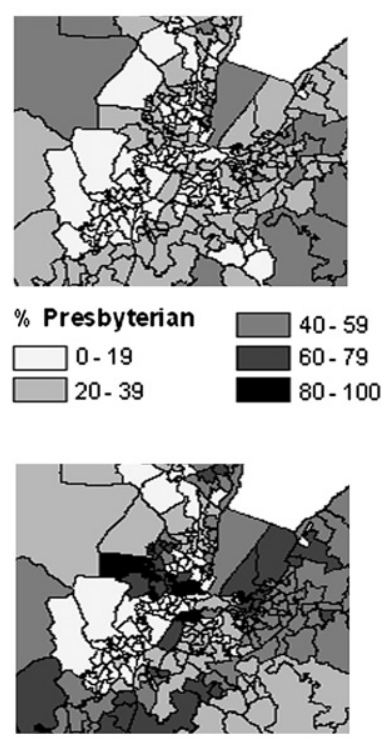

$\%$ Church of Ireland $\square 20-29$

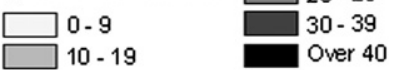

Fig. 1. (a-c) Distribution of the three main denominations by super-output area across Northern Ireland at the time of the 2001 Census.

causes of death, with risks associated with respiratory disease, all malignant neoplasms and lung cancer being particularly low. They also showed lower risks for circulatory disease though this was significant for men only. Men and women from the individual Protestant denominations generally had lower mortality from both lung cancer (all except the Church of Ireland) and stomach cancer. Also noteworthy was the reduced mortality risks for accidents in Methodists and 'Other
Christians'. There was little evidence of an increased risk of suicide amongst Protestant denominations, except perhaps for the 'Other Christian' women who had an $84 \%$ excess risk when compared against Catholic women. Table 5 shows mortality associated with alcohol consumption. With Catholics as the reference group 'Other Christians' show lowest mortality, with Presbyterian men and Methodists having excess risks (though significant only for women). 
Table 2

All-cause mortality for men and women aged 25-74 years enumerated at the Northern Ireland 2001 Census: by denomination in the five years after the census

\begin{tabular}{|c|c|c|c|c|c|c|}
\hline \multirow[b]{2}{*}{ Denomination } & \multicolumn{3}{|l|}{ Men } & \multicolumn{3}{|l|}{ Women } \\
\hline & Deaths & Adjusted for age & Fully adjusted $^{\mathrm{a}}$ & Deaths & Adjusted for age & Fully adjusted $^{\mathrm{a}}$ \\
\hline Roman Catholic & 6110 & 1.00 & 1.00 & 4628 & 1.00 & 1.00 \\
\hline Presbyterian & 4401 & $0.91 * * *(0.87,0.94)$ & $1.03(0.99,1.07)$ & 3119 & $0.86^{* * *}(0.82,0.90)$ & $0.93 *(0.88,0.97)$ \\
\hline Church of Ireland & 3585 & $1.01(0.97,1.05)$ & $1.05^{*}(1.01,1.10)$ & 2742 & $1.00(0.96,1.05)$ & $1.04(0.99,1.09)$ \\
\hline Methodist & 754 & $0.92(0.86,1.00)$ & $1.02(0.95,1.10)$ & 588 & $0.89 * *(0.82,0.97)$ & $0.95(0.87,1.04)$ \\
\hline Other Christian & 875 & $0.68 * * *(0.63,0.73)$ & $0.82 * * *(0.76,0.88)$ & 757 & $0.77 * * *(0.71,0.83)$ & $0.85^{* * *}(0.78,0.92)$ \\
\hline Other/none & 1070 & $1.02(0.96,1.09)$ & $0.99(0.93,1.06)$ & 662 & $1.03(0.95,1.12)$ & $0.96(0.88,1.05)$ \\
\hline All non-Catholics & 10,685 & $0.92 * * *(0.89,0.95)$ & $1.01(0.98,1.04)$ & 7868 & $0.91 * * *(0.88,0.94)$ & $0.96(0.92,1.00)$ \\
\hline
\end{tabular}

Source: Northern Ireland Longitudinal Study (Mortality Study).

Statistical significance: $* * * P<0.001 ; * * P<0.01 ; * P<0.05$.

Hazard ratios (and 95\% confidence intervals) from models fully adjusted for demographic and socio-economic factors.

${ }^{a}$ Model represents adjustment for age, marital status, educational attainment, social class, car availability, tenure, and population density of area of residence.

\section{Discussion}

This large representative study shows significant differences in mortality risk between the different denomination groups in Northern Ireland. Major differences in mortality between the Catholic and non-Catholic populations were largely explained by socio-economic circumstances, corroborating earlier ecological analyses from the 1981 and 1991 Censuses (O'Reilly \& Stevenson, 1998; Stringer, 1992). It also highlights wider differences between denominations within the Protestant community than between Catholics and Protestants: while Catholics are still, on average, marginally more disadvantaged than non-Catholics use of a summary non-Catholic group masks considerable differences within this group. This distinction is particularly acute for Church of Ireland members, whose socio-economic and mortality risk profiles mirror that of Catholics, and the 'Other Christian' group who generally experience lower mortality risk than other denominations.

The variation in cause-specific mortality hints at aetiological reasons for the differences between denominations. Variation in respiratory disease (especially lung cancer) and alcohol-related mortality points to lifestyle influence - for example low smoking prevalence and temperance in relation to alcohol. This was especially true for the more fundamentalist 'Other Christians'. While there is no absolute prohibition on alcohol or tobacco in this group, their interpretation of Christian scripture may emphasise moderation and make abstention the norm (Richardson, 1998). Many fundamental groups are the result of schism and may form tight, embracing communities which help regulate behavioural norms. This reflects research from the USA amongst groups such as Mormons and Seventh-day Adventists which highlight the salutary effects of religious observance (Heuch et al., 2005; Levin, 1994; Philips et al., 1978). Other studies of Mormon life, which demands avoidance of tobacco and alcohol, have shown that the degree of reduction in tobacco and alcoholrelated cancers is related to levels of adherence to church doctrine (Gardner \& Lyon, 1982). This relationship between mortality and behaviour in Northern Ireland remains speculative, as all health surveys over the last 20 years have limited analysis to differences between Catholics and Protestants only. They have shown that Catholics are more likely than Protestants to make adverse lifestyle choices, though the extent to which this is related to differences in socio-economic status is not known. In the 2001/02 Northern Ireland Health and Social Well-being Survey (NISRA, 2006a), 25\% of Catholics drank over the recommended alcohol limits (21 and 14 units per week for men and women, respectively) compared to Protestants (17\%) and more Catholics were regular smokers than Protestants (31\% and $22 \%$, respectively). In that analysis no adjustment was made for socio-economic status, though one study in the early 1990s showed that differences in potentially health damaging behaviour persisted even after such adjustment (Campbell \& Stevenson, 1993). These authors suggested that this may be a lag-effect in the Catholic community which, while experiencing recent upward social mobility, retained lifestyle characteristics more associated with earlier lower socio-economic status.

As noted (Fig. 1a-c) the Northern Ireland population is spatially segregated, with historic patterns of settlement changing little over the last 200 years (Wilson \& Spencer, 2006), a phenomenon due possibly to its rural nature and the custom of keeping land in the 
Table 3

All men aged 25-74 years enumerated at the 2001 Census of Northern Ireland: cause-specific mortality in the five years after the census by denomination

\begin{tabular}{|c|c|c|c|c|c|c|c|}
\hline Cause of death & Deaths (nos.) & Catholic & Presbyterian & Church of Ireland & Methodist & Other Christian & Other/none \\
\hline Circulatory disease & 5983 & 1.00 & $1.05(0.98,1.12)$ & $1.08 *(1.01,1.16)$ & $1.04(0.92,1.19)$ & $0.87 *(0.77,0.98)$ & $0.95(0.84,1.07)$ \\
\hline Ischaemic heart disease & 3961 & 1.00 & $1.01(0.93,1.09)$ & $1.06(0.98,1.16)$ & $1.06(0.91,1.24)$ & $0.88(0.76,1.02)$ & $0.91(0.78,1.05)$ \\
\hline Stroke & 1016 & 1.00 & $1.12(0.95,1.32)$ & $1.10(0.92,1.31)$ & $1.00(0.72,1.40)$ & $0.82(0.60,1.12)$ & $1.13(0.85,1.50)$ \\
\hline Respiratory disease & 1591 & 1.00 & $0.95(0.83,1.08)$ & $0.92(0.80,1.06)$ & $0.92(0.71,1.19)$ & $0.75 *(0.58,0.96)$ & $1.02(0.82,1.27)$ \\
\hline All malignant neoplasms & 5875 & 1.00 & $0.96(0.90,1.03)$ & $1.03(0.96,1.10)$ & $0.97(0.86,1.11)$ & $0.79 * * *(0.70,0.89)$ & $1.00(0.89,1.12)$ \\
\hline Lung cancer & 1648 & 1.00 & $0.86^{*}(0.75,0.97)$ & $1.00(0.88,1.14)$ & $0.72 *(0.55,0.94)$ & $0.58 * * *(0.45,0.75)$ & $0.87(0.70,1.08)$ \\
\hline Prostate & 438 & 1.00 & $1.22(0.96,1.56)$ & $1.10(0.84,1.44)$ & $1.00(0.61,1.62)$ & $0.91(0.60,1.39)$ & $1.00(0.64,1.59)$ \\
\hline Stomach & 309 & 1.00 & $0.64 * *(0.47,0.86)$ & $0.65^{*}(0.47,0.89)$ & $0.92(0.55,1.53)$ & $0.55^{*}(0.32,0.94)$ & $0.76(0.46,1.26)$ \\
\hline Oesophagus & 358 & 1.00 & $1.26(0.97,1.65)$ & $1.07(0.79,1.44)$ & $1.04(0.61,1.79)$ & $0.85(0.51,1.40)$ & $1.04(0.65,1.66)$ \\
\hline Colorectal & 712 & 1.00 & $1.04(0.85,1.30)$ & $1.11(0.91,1.36)$ & $1.28(0.92,1.78)$ & $0.77(0.55,1.09)$ & $0.62(0.41,0.93)$ \\
\hline All external causes & 845 & 1.00 & $1.15(0.96,1.37)$ & $1.01(0.83,1.23)$ & $0.72(0.47,1.12)$ & $0.96(0.71,1.30)$ & $1.00(0.75,1.33)$ \\
\hline Accidents & 454 & 1.00 & $1.19(0.94,1.51)$ & $1.03(0.79,1.34)$ & $0.42 *(0.20,0.90)$ & $0.83(0.53,1.29)$ & $1.02(0.69,1.50)$ \\
\hline Suicides & 348 & 1.00 & $0.95(0.72,1.26)$ & $0.92(0.68,1.25)$ & $1.15(0.67,1.96)$ & $1.03(0.66,1.59)$ & $0.81(0.51,1.28)$ \\
\hline
\end{tabular}

Source: Northern Ireland Longitudinal Study (Mortality Study)

Statistical significance: $* * * P<0.001 ; * * P<0.01 ; * P<0.05$

Hazard ratios (and 95\% confidence intervals) from models adjusted for demographic and socio-economic factors (model adjusted for age, marital status, education, social class, car availability,

tenure, and population density of area of residence).

Table 4

All women aged 25-74 years enumerated at the 2001 Census of Northern Ireland: cause-specific mortality in the five years after the census by denomination

\begin{tabular}{|c|c|c|c|c|c|c|c|}
\hline Cause of death & Deaths (nos.) & Catholic & Presbyterian & Church of Ireland & Methodist & Other Christian & Other/none \\
\hline Circulatory disease & 3574 & 1.00 & $0.96(0.88,1.05)$ & $1.11^{*}(1.01,1.21)$ & $1.02(0.87,1.20)$ & $0.86(0.74,1.00)$ & $1.06(0.90,1.25)$ \\
\hline Ischaemic heart disease & 1871 & 1.00 & $0.94(0.83,1.06)$ & $1.20 * *(1.06,1.36)$ & $0.95(0.75,1.19)$ & $0.86(0.70,1.06)$ & $1.15(0.92,1.43)$ \\
\hline Stroke & 921 & 1.00 & $0.88(0.74,1.05)$ & $0.88(0.73,1.06)$ & $1.23(0.92,1.64)$ & $0.82(0.61,1.11)$ & $0.73(0.51,1.06)$ \\
\hline Respiratory disease & 1322 & 1.00 & $0.86^{*}(0.73,0.99)$ & $1.02(0.88,1.18)$ & $0.85(0.65,1.12)$ & $0.71 * *(0.55,0.93)$ & $0.89(0.68,1.18)$ \\
\hline All malignant neoplasms & 5081 & 1.00 & $0.89 * *(0.83,0.96)$ & $0.95(0.88,1.03)$ & $0.90(0.79,1.03)$ & $0.83 * *(0.74,0.93)$ & $0.84 *(0.73,0.97)$ \\
\hline Lung cancer & 1017 & 1.00 & $0.63 * * *(0.53,0.74)$ & $0.96(0.82,1.12)$ & $0.77(0.57,1.04)$ & $0.45 * * *(0.32,0.62)$ & $0.85(0.63,1.14)$ \\
\hline Breast & 961 & 1.00 & $0.97(0.83,1.15)$ & $0.96(0.80,1.15)$ & $0.79(0.56,1.11)$ & $1.00(0.77,1.28)$ & $0.69 *(0.48,0.98)$ \\
\hline Stomach & 159 & 1.00 & $0.87(0.59,1.30)$ & $0.71(0.45,1.12)$ & $0.79(0.36,1.73)$ & $0.80(0.41,1.57)$ & $1.06(0.53,2.14)$ \\
\hline Oesophagus & 123 & 1.00 & $0.94(0.60,1.46)$ & $0.69(0.41,1.17)$ & $1.19(0.56,2.53)$ & $0.50(0.20,1.26)$ & $0.93(0.40,2.18)$ \\
\hline Colorectal & 471 & 1.00 & $0.84(0.66,1.06)$ & $0.93(0.73,1.20)$ & $0.55 *(0.32,0.95)$ & $1.01(0.71,1.43)$ & $0.92(0.59,1.43)$ \\
\hline All external causes & 377 & 1.00 & $0.99(0.76,1.29)$ & $1.04(0.79,1.38)$ & $0.67(0.36,1.24)$ & $0.87(0.55,1.36)$ & $0.96(0.59,1.55)$ \\
\hline Accidents & 226 & 1.00 & $0.96(0.69,1.33)$ & $.0 .82(0.57,1.19)$ & $0.44(0.18,1.08)$ & $0.41 *(0.19,0.90)$ & $0.89(0.48,1.67)$ \\
\hline Suicides & 129 & 1.00 & $1.01(0.61,1.64)$ & $1.45(0.91,2.30)$ & $1.08(0.43,2.74)$ & $1.84(1.00,3.36)$ & $0.76(0.30,1.90)$ \\
\hline
\end{tabular}

Source: Northern Ireland Longitudinal Study (Mortality Study).

Statistical significance: $* * * P<0.001 ; * * P<0.01 ; * P<0.05$.

Hazard ratios (and $95 \%$ confidence intervals) from models adjusted for demographic and socio-economic factors (model adjusted for age, marital status, education, social class, car availability,

tenure, and population density of area of residence). 
Table 5

Those enumerated at the 2001 Census of Northern Ireland aged 25-74 years: mortality related to alcohol consumption in the five years following the census, by denomination

\begin{tabular}{|c|c|c|c|c|c|c|c|}
\hline $\begin{array}{l}\text { Mortality related } \\
\text { to alcohol } \\
\text { consumption }\end{array}$ & $\begin{array}{l}\text { Deaths } \\
\text { (nos.) }\end{array}$ & Catholic & Presbyterian & $\begin{array}{l}\text { Church of } \\
\text { Ireland }\end{array}$ & Methodist & Other Christian & Other/none \\
\hline Males $^{\mathrm{a}}$ & 600 & 1.00 & $1.33 *(1.08,1.64)$ & $1.07(0.85,1.34)$ & $1.33(0.89,1.97)$ & $0.67(0.42,1.07)$ & $1.08(0.77,1.47)$ \\
\hline Females $^{\mathrm{a}}$ & 303 & 1.00 & $0.92(0.67,1.27)$ & $1.21(0.89,1.65)$ & $1.74 *(1.10,2.76)$ & $0.60(0.32,1.11)$ & $1.57(1.01,2.41)$ \\
\hline All persons ${ }^{\mathrm{b}}$ & 903 & 1.00 & $1.19(1.00,1.42)$ & $1.12(0.93,1.35)$ & $1.48 *(1.10,2.00)$ & $0.63 *(0.44,0.92)$ & $1.24(0.96,1.60)$ \\
\hline
\end{tabular}

Source: Northern Ireland Longitudinal Study (Mortality Study).

Statistical significance: $* P<0.05$.

Hazard ratios (and 95\% confidence intervals) derived from models fully adjusted for demographic and socio-economic factors.

a Model adjusted for age, marital status, education, social class, car availability, tenure, and population density of area of residence.

b Model adjusted as above, but also includes sex.

family. This, aligned with a past tendency to marry within the same religious group suggests the possibility of genetically determined differences, though other familially patterned factors such as diet may also be operating.

The higher stomach cancer levels amongst Catholics deserve comment. It is known to be associated with Helicobacter Pylori infection (Parkin, 2006), itself associated with larger family size (Ueda, Kikuchi, Kasugai, Shunichi, \& Miyake, 2003) and higher childhood deprivation levels (Malcolm, MacKay, Shepherd, \& Weaver, 2004), both of which are more common amongst Catholics. This study also showed that Methodists and 'Other Christians' had lower mortality from accidents, which may reflect either a tendency towards lower risk behaviour or incomplete adjustment for residential characteristics these denominations are associated with urban living while accidents are more associated with rurality (O'Reilly et al., in press).

This study has limitations which should be acknowledged. As with all census-based longitudinal studies data were limited to that provided in the census. Religious affiliation in early life was used as a proxy for affiliation for those who left the current religion question unanswered. This is probably justified: it reflects socio-economic and cultural influences associated with identity and other factors that probably do not change much over the life-course. A similar approach has been adopted with the Scottish Census (Walls, 2001). However, while this is evidence of affiliation it says little about observance or adherence, which may be additionally salutogenic. For example, frequency of church attendance is associated with lower mortality (Strawbridge, Cohen, Shema, \& Kaplan, 1997), an effect that might be mediated through improved social networks, and this protective effect has been noted even in those who attend church as infrequently as once or twice a year (la Cour, Avlund, \& SchultzLarsen, 2006). Finally, even with this large data set the relatively small numbers of events recorded for less common causes of death produce less stable hazard ratios, and it is recommended that greater emphasis be placed on general trends to avoid over-interpreting specific results.

In conclusion, this study has shown that, in Northern Ireland, religious affiliation can have a significant effect on all-cause and cause-specific mortality. Further work is necessary to understand the mechanisms influencing these variations. Given the association between mortality, denomination and spatial distribution, this may explain some of the known geographical variation in mortality in Northern Ireland (NISRA, 2006b) and may be worth considering when designing health promotion interventions. It is recognised that church attendance is generally higher in Northern Ireland than other parts of the UK, though trends are converging (Richardson, 1998), and this may be associated with corresponding changes in lifestyle, behaviour and well-being.

\section{Acknowledgements}

The help provided by the staff of the Northern Ireland Longitudinal Study (NILS) is acknowledged. The NILS is funded by the Department of Health and Social Services and Public Health, and the Research and Development Office of the Health and Personal Services. The authors alone are responsible for the interpretation of the data.

\section{References}

Abbotts, J., Williams, R., Ford, G., Hunt, K., \& West, P. (1997). Morbidity and Irish Catholic descent in Britain: an ethnic and 
religious minority 150 years on. Social Science \& Medicine, 45, 3-14.

Borooah, V. (1999). Is there a penalty to being a Catholic in Northern Ireland? An econometric analysis of the relationship between religious belief and occupational success. European Journal of Political Economics, 15, 163-192.

Borooah, V. (2000). Targeting social need: why are deprivation levels in Northern Ireland higher for Catholics than for Protestants? Journal of Social Policy, 29, 281-301.

Campbell, R. (1993). Research into inequalities in health in Northern Ireland: what research? Critical Public Health, 4, 5-8.

Campbell, R., \& Stevenson, G. (1993). Community differentials in health in Northern Ireland: A report to the Northern Ireland Department of Health and Social Services.

Compton, P. (1986). Demographic trends in Northern Ireland. Belfast: Northern Ireland Economic Council.

la Cour, P., Avlund, K., \& Schultz-Larsen, K. (2006). Religion and survival in a secular region. A twenty year follow-up of 734 Danish adults born in 1914. Social Science \& Medicine, 62, 157-164.

DRD (Northern Ireland). (2007). Department for Regional Development. Available from: http://www.drdni.gov.uk/DRDwww_ EquityAgenda/. (Accessed March 2007).

Durkheim, E. (1959). Suicide: A study in sociology. New York, NY: Free Press.

Gardner, J., \& Lyon, J. (1982). Cancer in Utah Mormons men by lay priesthood level. American Journal of Epidemiology, 116, 243-257.

GRO (Scotland). (2007). General Register Office for Scotland. Available from: http://www.gro-scotland.gov.uk/statistics/publications-anddata/annual-report-publications/rgs-annual-review-2005/chapter-2/ chapter-2-causes-of-death-statistics-trends/chapter-2-alcohol-relateddeaths.html. (Accessed May 2007).

Heuch, I., Jacobsen, B. K., \& Fraser, G. E. (2005). A cohort found that earlier and longer Seventh-day Adventist church membership was associated with reduced male mortality. Journal of Clinical Epidemiology, 58(1), 83-91.

Hummer, R. A., Ellison, C. G., Rogers, R. G., Moulton, B. E., \& Romero, R. R. (2004). Religious involvement and adult mortality in the United States: review and perspective. Southern Medical Journal, 97, 1223-1230.

Koenig, H. G., McCullough, M. E., \& Larson, D. B. (2001). Handbook of religion and health. Oxford: Oxford University Press.

Levin, J. S. (1994). Investigating the epidemiologic effects of religious experience. In J. S. Levin (Ed.), Religion in aging and health (pp. 3-17). Thousand Oaks: California Sage Publications.

McCullough, M., Hoyt, W., Larson, D., Koenig, H., \& Thoresen, C. (2000). Religious involvement and mortality: a meta-analytic review. Health Psychology, 19, 211-222.

McKittrick, D., Kelters, S., Feeney, B., \& Thornton, C. (1999). Lost Lives: The stories of the men, women and children who died as a result of the Northern Ireland troubles. Edinburgh: Mainstream Publishing Company.

Malcolm, C. A., MacKay, W. G., Shepherd, A., \& Weaver, L. T. (2004). Helicobacter pylori in children is strongly associated with poverty. Scottish Medical Journal, 49, 136-138.

NISRA. (1997). Northern Ireland Statistics and Research Agency. Focus on Northern Ireland: A statistical profile. London: Stationary Office.
NISRA. (2000). Northern Ireland Statistics and Research Agency. Labour Force Survey (LFS) Religion Report. Belfast: NISRA.

NISRA. (2006a). Northern Ireland Statistics and Research Agency. Continuous Household Survey. Available from: http://www.csu.nis ra.gov.uk/surveys/survey.asp?id=1\&details $=3$ (Accessed June 2006).

NISRA. (2006b). Northern Ireland Statistics and Research Agency. Registrar General Northern Ireland Annual Report 2005. Available from: www.nisra.gov.uk (Accessed November 2006).

O'Grada, C., \& Walsh, B. (1995). Fertility and population in Ireland: north and south. Population Studies, 49, 259-279.

ONS. (2007). Office for National Statistics. ONS - defining alcohol related deaths. Available from: www.statistics.gov.uk/downloads/ theme_health/Summary_responses.pdf (Accessed May 2007).

O'Reilly, D., \& Browne, S. (2001). Health and health services use in Northern Ireland: Social variations. Report to the Department of Health, Social Services and Public Safety.

O'Reilly, D., Rosato, M., \& Connolly, S. Unlinked vital events in census based longitudinal studies can bias subsequent analysis. Journal of Clinical Epidemiology, in press.

O'Reilly, D., \& Stevenson, M. (1998). The two communities in Northern Ireland: deprivation and health. Journal of Public Health Medicine, 20, 161-168.

O'Reilly, D., \& Stevenson, M. (2003). Mental health in Northern Ireland: have 'the Troubles' made it worse? Journal of Epidemiology and Community Health, 57, 488-492.

Parkin, D. M. (2006). The global health burden of infectionassociated cancers in the year 2002. International Journal of Cancer, 118, 30-44.

Philips, R., Lemon, F., Beeson, W. L., \& Kuzma, J. (1978). Coronary heart disease mortality among Seventh-day Adventists with differing dietary habits: a preliminary report. American Journal of Clinical Nutrition, 31, S191-S198.

Rose, D., \& Pevalin, D. (2002). A researcher's guide to the National Statistics Socio-economic Classification. London: Sage Publications.

Richardson, N. (1998). A tapestry of beliefs: Christian traditions in Northern Ireland. Belfast: Blackstaff Press.

StataCorp. (2005). Stata statistical software: Release 9. College Station, TX: StataCorp LP.

Strawbridge, W., Cohen, R., Shema, S., \& Kaplan, G. (1997). Frequent attendance at religious services and mortality over 28 years. American Journal of Public Health, 87, 957-961.

Stringer, P. (1992). Health inequalities, religious affiliation and urban-rural status. A report to the Department of Health and Social Services (NI). Belfast: DHSS.

Ueda, M., Kikuchi, S., Kasugai, T., Shunichi, T., \& Miyake, C. (2003). Helicobacter pylori risk associated with childhood home environment. Cancer Science, 94, 914-918.

Walls, P. (2001). Religion, ethnicity and nation in the census: some thoughts on the inclusion of the inclusion of Irish ethnicity and Catholic religion. Radical Statistics, 78, 48-62.

Williams, R. (1994). Britain's regional mortality: a legacy from disaster in the Celtic periphery? Social Science \& Medicine, 39, 189-199.

Wilson, D., \& Spencer, M. (Eds.), (2006). Ulster Presbyterians in the Atlantic World: Religion, politics and identity. Dublin: Four Courts Press Ltd. 